\title{
POPULATION DYNAMICS AND DISTRIBUTION PATTERNS OF DIURNAL RAPTORS IN NORTHEASTERN ALGERIA: SEASONAL VARIATION AND SOME NESTING CHARACTERISTICS
}

\author{
ALI ELAFRI $^{1 *}$, OKBA BOUMAAZA ${ }^{2}$, MOHAMED DHAYA EL-HAK KHEMIS ${ }^{3}, \mathrm{KHIE}^{-}$ \\ REDIN BOUCHERIT ${ }^{2}$, MOUSSA HOUHAMDI ${ }^{2}$
}

${ }^{1}$ Département de Biologie, Faculté des Sciences de la Nature et de la Vie, Université Abbés Laghrour, Khenchela, Algeria; e-mail: a.elafri@centre-univ-mila.dz, alielafri@gmail.com

${ }^{2}$ Laboratoire Biologie, Eau et Environnement (LBEE), Faculté SnV-STU, Université 8 Mai 1945 Guelma, Algeria; e-mail: houhamdimoussa@yahoo.fr

${ }^{3}$ Département de Biologie, Faculté des Sciences de la Nature et de la Vie, Université Badji Moukhtar, Annaba, Algeria; e-mail: khemis.dhaya@yahoo.com

${ }^{*}$ Author for correspondence

Abstract

Elafri A., Boumaaza O., Khemis M.D.E., Boucherit K., Houhamdi M.: Population dynamics and distribution patterns of diurnal raptors in northeastern Algeria: seasonal variation and some nesting characteristics. Ekológia (Bratislava), Vol. 39, No. 1, p. 58-71, 2020.

Providing a live data monitoring of raptor abundances and spatial localization of their most important nesting areas is very helpful in building a strong future study and applying a sound strategy for effective safeguarding of these emblematic species. Using geographic information system (GIS) and global positioning system (GPS) techniques, we investigated spatial patterns of raptors distribution in the northeastern areas of Algeria during two consecutive breeding seasons (2014 and 2015). The total area sampled $\left(31,000 \mathrm{~km}^{2}\right)$ host diverse raptor species (14 species), among them, the threatened species Egyptian vulture (Neophron percnopterus; 108 individuals and 19 active nests) and red-footed falcon (Falco vespertinus; 12individuals). The value of the region is attested by the presence of an abundant population of nesting black kite (Milvus migrans; 337 individuals). The large-scale spatial analyses of the studied region illustrate certain similarities in nesting habitat selection among raptors. Almost all species (90\% of 209 nests detected) preferred to nest within multispecies assemblages (20 raptor assemblages found) and occupied altitudinal rocky cliffs across the inland region (semi-arid zones) rather than coastal region (sub-humid zones). Among all raptor species, exclusively, the common kestrel (Falco tinnunculus) is relatively synanthropic, because it was found to breed within cities (tolerate human activities). The raptor community in the coastal versus inland regions differed by $14 \%$. The latter area seems to be more preferred in nest building, probably consequence of their semi-arid bioclimatic and landscapes characteristics, where high elevations and grasslands forming mosaics with Oak, Alpine, and Cedar forests are patchily distributed. The study is a first mapping database of important nesting sites dispatched across the northeastern areas of Algeria, and it can be effectively used in future complementary researches that aim to elucidate environmental factors that affect raptors life cycle.

Key words: raptor assemblages, cliff nesting, roadside point transect, inland regions, GIS. 


\section{Introduction}

Raptors or "Bird of prey" refers to vulture, hawks, eagles, falcons, ospreys, and their allies; all of which are adapted for a lifestyle of aerial hunting (Ferguson-Less, Christie, 2001; Weidensaul, 1996). As organisms at the end of terrestrial food chains and aquatic food webs, these birds are both biologically important (i.e., important ecological role in controlling populations of rodents and other small mammals) and environmentally sensitive, which serves as a barometer of wild ecological health (i.e., indicators of worldwide pollution by pesticide; Weidensaul, 1996; Virani, Watson, 1998; Bildstein, 2006). They can also be used as "umbrella species" because their large home ranges and low nesting densities necessitate that any protected areas encompassing viable populations or complete communities protect sufficient habitat and populations of most, if not all, other species in the food web below them (Virani, Watson, 1998). Finally, an abundance and diversity of raptors invariably signals a largely undisturbed ecosystem (measure of our impact on landscapes, even in remote area), supporting an abundance of other wildlife (Weidensaul, 1996; Virani, Watson, 1998; Bildstein, 2006).

The population status and distribution of raptor species can be difficult to estimate because they are often dispersed and/or secretive species that nest in low densities (with large individual area needs), and their population can fluctuate cyclically in relation to prey abundance (Kirk, Hyslop, 1998). This can make raptors studies challenging, and many species remain poorly known around the word (Bildstein et al., 1998; Bierregaard, 1998; Watson, 1998). In the recent decades, raptors have become gradually more protected, and several species have becomes significant "flagships" for increasing public interest and support of conservation programs around the world, but their decline often persists, because of pollution, habitat alteration, and fragmentation or direct/indirect human disturbance (Virani, Watson, 1998; Brambilla et al., 2004). Their declining numbers and economic relationships warrant additional interest, and studies of total raptor populations are needed as a means by which we may elucidate their responses to changing pressures and environmental conditions (Smith, Murphy, 1973).

In Algeria, birds have been intensively studied but the focus often was on water-related birds, passeriformes and doves. Apart from the rudimentary censuses performed by Moali and Gaci (1992) and Moali and Isenman (1990), birds of prey, however, have been carried out by a relatively few biologists who only documented the dietary and nesting characteristics of only some single species (as in Souttou et al., 2006, 2007; Telailia et al., 2013). Hence, there have been no attempts to describe spatial ecology and raptor community composition in detail comparable to those of raptor researchers around the world (see Thiollay 1977a, b, 1989, 2007; Piana, Marsden, 2012; Zilio et al., 2013).

In this article, we aim at filling these gaps of knowledge by examining the raptor assemblage patterns in northeastern Algeria, in terms of species richness, abundance, and breeding characteristics, and the main environmental drivers of assemblage patterns in order to establish a live data observatory that can help build the local expertise needed to monitor these emblematic species in the future and implement a sound strategy for their effective safeguarding.

\section{Material and methods}

Study area

Field data were collected from seven provinces (Wilaya) of northeastern Algeria (Mila, Constantine, Oum El-bouaghi, Guelma, Annaba, El-Taref, and Souk-Ahrass), historically known as Numidia $\left(37^{\circ} 08^{\prime}\right.$ and $35^{\circ} 41^{\prime} \mathrm{N}, 5^{\circ} 48^{\prime}$ and $\left.8^{\circ} 68^{\prime} \mathrm{E}\right)$ (Isenmann, 
Moali 2000; PASNB, 2003). It is a region with an area of about $31,000 \mathrm{~km}^{2}$ with considerable landscapes and climates variation and where both forest and agricultural lands occupy two-thirds of the total area (Isenmann, Moali 2000; Coulthard, 2001; PASNB, 2003). Geographically, the study area can be divided into two distinct regions of topography and climate. From the Mediterranean Sea southwards, we can recognize two main ecoregions.

\section{The coastal strip}

This zone covers the northern part of Numidia; it is located in the humid and sub-humid bioclimatic zones receiving more than 1,000 mm of rainfall per year, with 3-4 months during the northern summer (July/August to October) (Isenmann, Moali 2000; Coulthard, 2001; PASNB, 2003). It is an area dotted with woodlands dominated by holm oak (Quercus ilex), cork oak (Q. suber), xen oak (Q. canariensis), Aleppo pine (Pinus halepensis), maritime pine (P. pinaster), atlas cedar (Cedrus atlantica), and Mediterranean scrub (also called as maquis/macchia or garrigue). This area can also characterized by woody vegetation including wild olive tree (Olea europaea var. sylvestris), dwarf palm (Chamaerops humilis), Oleander (Nerium oleander), and lentisk (Pistacia lentiscus) (Isenmann, Moali, 2000; PASNB, 2003). The valleys and low-lying plains of the region include the most fertile and productive arable agricultural land in Algeria, and most of the large centers of human population are concentrated here (Coulthard, 2001; Samraoui, Samraoui, 2008).

\section{The inland region (hauts-plateaux)}

Highlands occupy the southern part of Numidia and is located in the semi-arid zones receiving 100-200 mm of annual rainfall (Isenmann, Moali, 2000; PASNB, 2003). The Hauts Plateaux consists of a huge basin, lying at fairly high altitude between the parallel mountain ranges of the Tell Atlas to the north and the Saharan Atlas to the south (Coulthard, 2001; Samraoui, Samraoui, 2008). This area is steppes that are mostly used extensively for sheep rearing and covered with alfa grass (Stipa tenacissima), wormwood (Artemisia herba-alba), and Lygeum spartum (Isenmann, Moali, 2000; PASNB, 2003). On this region, there are large areas of wheat cultivation and heavy grazing by cattle, sheep, and goats on non-arable areas (Coulthard, 2001).

\section{Data collection}

\section{Raptor abundance}

An average of 10 roadside (on each road) surveys were conducted on 27 different routes for 2 consecutive breeding seasons (from March to August of 2014 and 2015) covering an area of 1,363 km in length and about $70 \%$ of the study region (Fig. 1). Each route was surveyed six times in the two breeding seasons. All surveys were conducted between $08: 00$ and 16:30 at vehicle speeds of $40 \mathrm{~km} / \mathrm{h}$ or less. Brief stops were made to identify and record observed birds. Only birds initially seen with the unaided eye were recorded. Binoculars $(10 \times 40$ and $8 \times 42)$ were used to aid in identification.

\section{Raptor nesting and assemblages}

The majority of the raptor species likely to nest on raised natural substrates (especially trees and cliffs). Also, it should be noted that none of the cavity and burrow nesting species excavate their own nests and are, therefore, dependent on the presence of existing cavities or burrows (Bird, Bildstein, 2007; ULRP, 2013). As a result, searches for cliff cavities, tree cavities, or burrows can be a useful way to identify potential nesting sites before the nesting season (Bird, Bildstein, 2007; ULRP, 2013). According to these suggestions, we collected data on raptors and their habitats for a set of cliffs where breeding activity was recorded at least once between early March and early September in the years 2014 and 2015. Along the 27 routes (roadside point transect) overall, active cliffs and assemblage sites were recorded and located with a GPS, plotted on 1:50,000 topographic maps (Arc/ Map 10; ESRI, 2010). Also we have created a separate sensitivity map (MapInfo, 2010) for the most abundant raptor species.

\section{Data analysis}

We calculated the total number of individuals detected on all surveys, as well as species totals, relative abundance $(\%)(\mathrm{n} / \mathrm{N} \times$ 100 , where $\mathrm{n}$ is the count of a particular bird species and $\mathrm{N}$ is the total number of individuals counted for all species during each count session), regional occurrence (frequency of detection: we divided the number of surveys during which the species was recorded by the total number of conducted surveys), Jaccard s coefficient of community similarity (it is a measurement of similarity for two samples, with a range from 0 to $100 \%$, the higher the percentage is, the more similar is the two populations: 
$J=$ numbers of species shared between both regions/the total number of species shared and un-shared $\times 100)$, and Shannon diversity index $\left(\mathrm{H}^{\prime}=[\Sigma \mathrm{Pi} \ln \mathrm{Pi}]\right.$, where $\mathrm{H}^{\prime}=$ diversity index; $\mathrm{Pi}=$ is the proportion of each species in the sample) (Magurran, 1988). We classified relative abundance into four species abundance classes: very common (10-26\% of all individuals

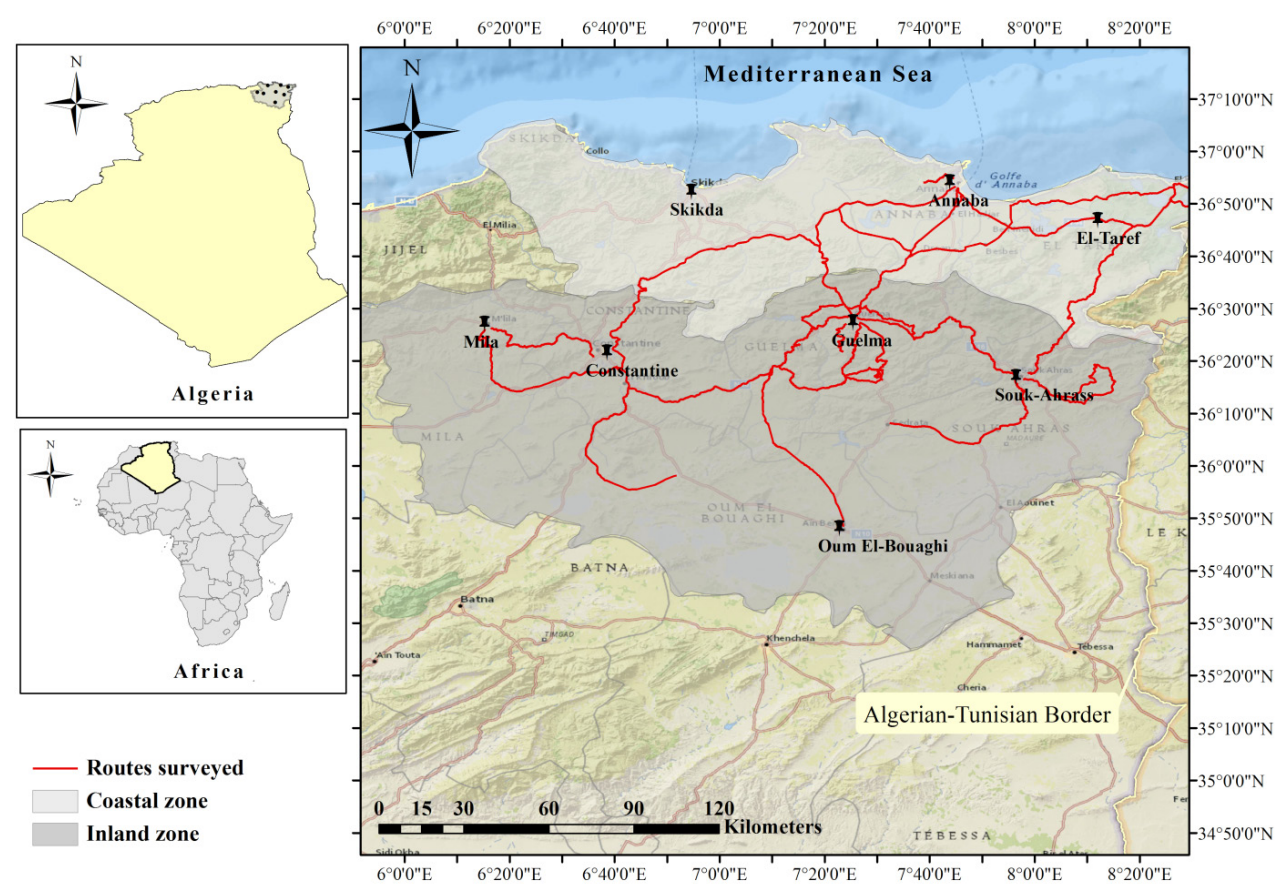

Fig. 1. Map showing the study region and the surveyed routes (MapInfo 2010 by authors).

detected), common (3-5\%), uncommon (1-2\%), and rare (<1\%) (Jensen et al., 2005). We used BioDiversity Pro 2.0 software to generate a species accumulation curve to evaluate the probability that our 2-year, 27-route, roadside, survey design was adequate for documenting all detectable raptor species (Jensen et al., 2005).

We then calculated the mean number of individuals per species per route (mean number per route) by year and region. For this comparison, we used the 27 routes surveyed in the 2 years: inland region (17 routes) and coastal region (10 routes). For all inventoried species, we used paired t-tests to evaluate two hypothesis ( 1 : mean number per route $2014=$ or $\neq$ mean number per route 2015; 2 : mean number per route inland region $=$ or $\neq$ mean number per route coastal region). Differences were considered significant at $\mathrm{P}<0.05$.

\section{Results}

\section{Diversity abundance and status of diurnal raptors}

We counted 936 raptors representing 14 species under 3 families (Table 1). Accipitridae with 9 species is the richest family in species number, followed by Falconidae (4 species) and Pandionidae with only 1 species. The three most abundant species, black kite (Milvus migrans), common 
kestrel (Falco tinnunculus), and Egyptian vulture (Neophron percnopterus), comprised $70 \%$ of all individuals and are seen on $90-96 \%$ of all routes. The four rare species, Bonelli's eagle (Aquila fasciata), short-toed snake eagle (Circaetus gallicus), red-footed falcon (Falco vespertinus), and western osprey (Pandion haliaetus) have the relative abundance of $\leq 1 \%$ of all individuals seen and are detected on $<30 \%$ of all the routes. Three additional species, the booted eagle (Hieraaetus pennatus), long-legged buzzard (Buteo rufinus), and black-winged kite (Elanus caeruleus), are classified as common and together comprised $15 \%$ of all individuals. The remaining species are uncommon and have the relative abundance of 1-3\%. Species classified as common are detected on $56-92 \%$ of all the routes, whereas uncommon species are detected on $10-40 \%$ of the routes. In accordance with the BirdLife Checklist Version_7(2014), only the Egyptian vulture have the endangered species status, while the red-footed falcon (Falco vespertinus) is considered to be near threatened. The remaining species are assigned the status of "Least Concern" (Table 1).

There are at least 14 species of raptor in the region. The fact that the curve seems to level off after the 24 routes are added up might indicate that most of the species have been found (Fig. 2). Otherwise, the number of surveyed routes is adequate for documenting all species detectable by roadside point count surveys in the study area. Specifically, all 14 species are detected with 24 routes ( $85 \%$ of all routes surveyed).

\section{Yearly comparisons}

Among the 14 raptor species detected in this study, no significant differences are observed in the mean number per route (both p-value more than 0.05 under one-sample t-test) between the two years of study (Table 2). There are no annual changes in the actual population size of northeastern Algeria's raptors.

\section{Regional comparisons}

The greatest number of species (14) is detected in the coastal region (Fig. 3). However, species numbers were relatively similar between the regions. The diversity index was higher in the coastal zone during both the years. Species accumulation curves indicated that the number of routes surveyed during each season is adequate to detect the majority of species for both regions (Fig. 4). The raptor community (Jaccard's coefficient of community similarity) in the coastal region versus inland region differed by $14 \%$. However, 12 species were shared in each region.

Seven of the 14 species exhibited regional differences in the mean number per route $(\mathrm{p}<0.05$ under one-sample t-test; Fig. 5). The red-footed falcon, short-toed snake eagle, black-winged kite, western marsh harrier, and western osprey are more numerous in the coastal region than in the inland region during the breeding seasons. In contrast, the two vultures are abundant in the inland zone.

\section{Nest characteristics and distribution}

Three varieties of raptor nest building strategies have been detected in northeastern Algeria (Table 3). Almost all raptor species prefer to nest on cliff face recesses ( $90 \%$ of all nests detected during 
$\mathrm{T}$ a b 1 e 1. Ecological status and relative abundance of diurnal raptorsinventoried in the northeastern region of Algeria during the breeding periods of 2014 and 2015.

\begin{tabular}{|l|l|c|c|c|l|}
\hline Family & Scientificnames & Total & $\begin{array}{c}\text { Ooccurrence } \\
\text { frequency(\%) }\end{array}$ & $\begin{array}{c}\text { Relative } \\
\text { abundance }\end{array}$ & Status $^{* *}$ \\
\hline Accipitridae & Milvus migrans & 337 & 96.43 & 0.36 & Least concerned \\
\hline & Hieraaetus pennatus & 66 & 92.86 & 0.07 & Least concerned \\
\hline & Aquila fasciata & 17 & 39.29 & 0.01 & Least concerned \\
\hline & Buteo rufinus & 52 & 85.71 & 0.05 & Least concerned \\
\hline & Circus aeruginosus & 19 & 10.71 & 0.02 & Least concerned \\
\hline & Elanus caeruleus & 34 & 46.43 & 0.03 & Least concerned \\
\hline & Circaetus gallicus & 16 & 32.14 & 0.01 & Least concerned \\
\hline & Gyps fulvus & 22 & 3.5 & 0.02 & Least concerned \\
\hline & Neophron percnopterus & 108 & 57.14 & 0.11 & Endangered \\
\hline & Falco peregrinus & 23 & 32.14 & 0.02 & Least concerned \\
\hline & Falco tinnunculus & 209 & 89.29 & 0.22 & Least concerned \\
\hline & Falco biarmicus & 19 & 25.00 & 0.02 & Least concerned \\
\hline & Falco vespertinus & 12 & 3.57 & 0.01 & Nearthreatened \\
\hline & Pandion haliaetus & 2 & 7.14 & 0.002 & Least concerned \\
\hline
\end{tabular}

${ }^{*}$ Relative abundanceclass: Very common $=10-26 \%$ of all individuals detected; Common $=5-10 \%$, Uncommon $=$ $1-5 \%$, Rare $\leq 1 \%$. ${ }^{*}$ Bird Life Checklist Version_7 (2014).

$\mathrm{T}$ a b l e 2. Mean number of individuals $( \pm \mathrm{SD})$ detected per route (mean/route) during diurnal raptor surveys in the north-east of Algeria during the tow breeding seasons (2014 and 2015).

\begin{tabular}{|l|c|c|c|}
\hline & $\mathbf{2 0 1 4}$ & $\mathbf{2 0 1 5}$ & One-sample t-test \\
\hline Black Kite & $4.54( \pm 2.69)$ & $4.04( \pm 2.33)$ & $\mathrm{t}=-0.74, \mathrm{p}=0.46$ \\
\hline Booted Eagle & $2.50( \pm 1.23)$ & $2.00( \pm 1.28)$ & $\mathrm{t}=1.49, \mathrm{p}=0.14$ \\
\hline Bonelli's Eagle & $0.61( \pm 0.92)$ & $0.54( \pm 0.79)$ & $\mathrm{t}=-0.31, \mathrm{p}=0.75$ \\
\hline Long-legged Buzzard & $1.50( \pm 1.07)$ & $1.29( \pm 0.76)$ & $\mathrm{t}=0.86, \mathrm{p}=0.39$ \\
\hline Peregrine Falcon & $0.61( \pm 1.07)$ & $0.57( \pm 0.92)$ & $\mathrm{t}=-0.13, \mathrm{p}=0.89$ \\
\hline Common Kestrel & $5.00( \pm 2.72)$ & $5.04( \pm 2.59)$ & $\mathrm{t}=-0.05, \mathrm{p}=0.96$ \\
\hline Lanner Falcon & $0.46( \pm 0.92)$ & $0.50( \pm 0.92)$ & $\mathrm{t}=0.14, \mathrm{p}=0.88$ \\
\hline Egyptian Vulture & $1.39( \pm 1.52)$ & $1.39( \pm 1.45)$ & $\mathrm{t}=-0.03 \cdot \mathrm{p}=0.98$ \\
\hline Red-footed Falcon & $0.39( \pm 2.08)$ & $0.43( \pm 2.27)$ & $\mathrm{t}=0.06 \cdot \mathrm{p}=0.95$ \\
\hline Short-toed Snake Eagle & $0.57( \pm 0.96)$ & $0.57( \pm 1)$ & $\mathrm{t}=0.02 \cdot \mathrm{p}=0.94$ \\
\hline Griffon Vulture & $1.1( \pm 0.77)$ & $1.32( \pm 0.72)$ & $\mathrm{t}=0.07 \cdot \mathrm{p}=0.98$ \\
\hline Black-winged Kite & $1.21( \pm 1.55)$ & $1.21( \pm 1.47)$ & $\mathrm{t}=0.04 \cdot \mathrm{p}=0.96$ \\
\hline Western Marsh Harrier & $0.68( \pm 2.87)$ & $0.68( \pm 2.72)$ & $\mathrm{t}=0.03 \cdot \mathrm{p}=0.95$ \\
\hline Western Osprey & $0.07( \pm 0.26)$ & $0.07( \pm 0.26)$ & $\mathrm{t}=0.02 \cdot \mathrm{p}=0.096$ \\
\hline
\end{tabular}

raptor surveys). Black kite, booted eagle, long-legged buzzard, and black-winged kite have also built their nests with very low proportion (6\% of all nests detected) on sturdy trees. The best trees for these sorts of nests are cork oak (Quercus suber), large eucalypts, and pines. Exceptionally, common kestrel exhibited an anthropogenic character because some nests have been found on 


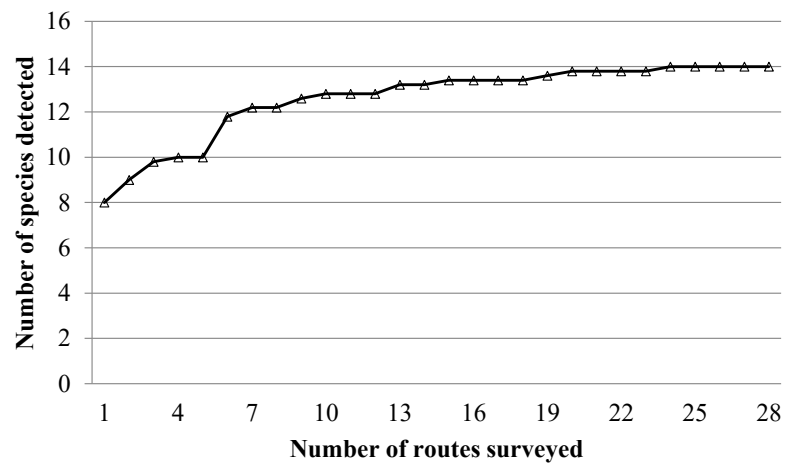

Fig. 2. Species accumulation graph of raptor species detected in 28 survey routes in the northeastern region of Algeria during the two breeding seasons.

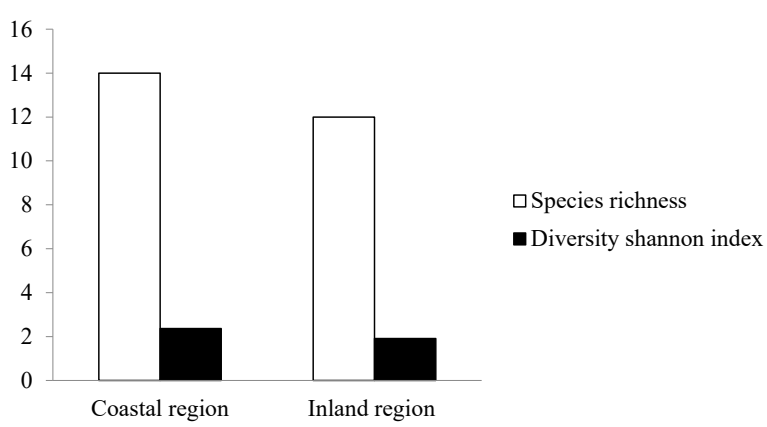

Fig. 3. Raptor species numbers and diversity in the coastal and inland regions of northeastern Algeria for combined years during the breeding seasons (2014 and 2015).

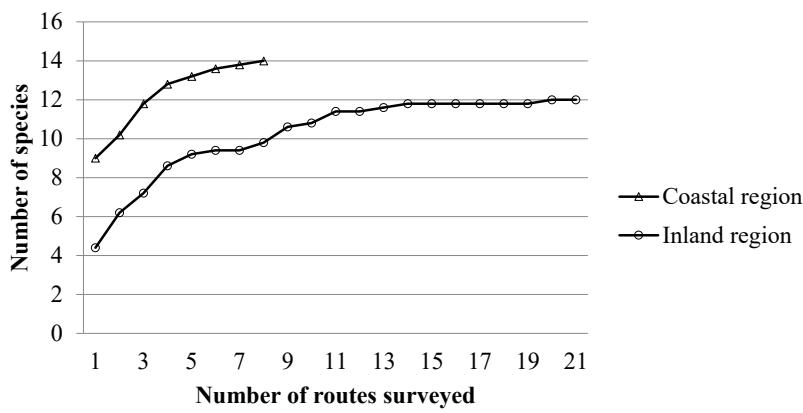

Fig. 4. Species accumulation curves for raptors detected in the coastal and inland regions of northeastern Algeria for combined years during the breeding seasons (2014 and 2015). the ledges of high-rise buildings in or around cities. Black kite and common kestrel nests are reported most frequently than the other birds (Table 3) and in the highest numbers (82 and 57 nests, respectively) followed by the Egyptian vulture (19) and booted eagle (17). Among the 20 raptor assemblages with 186 nests detected (Fig. 6; Table 3), the greatest concentration of raptor nests occurs in the inland zone ( $95 \%$ of all nests detected during raptor surveys). Only one raptor assemblage is detected in the coastal region. In addition, almost all the raptor species (18 assemblages) are found nesting at a higher altitude and all most on active cliffs located at $900-1,000 \mathrm{~m}$ in distance from the sea (Fig. 7).

\section{Discovering raptor species nests}

We describe in this section nest characteristics and locations of the four most frequented raptor species:

Black Kite (Milvus migrans)

This species is widely distributed throughout the inland region from $6^{\circ} 10^{\prime} 0^{\prime \prime} \mathrm{E}$ to the Algerian-Tunisian border (Fig. 8). Nests are typically found on high cliff and rock ledges. The number of active nests within each assemblage varies from 2 to 16 . Guelma province is the most important nesting area. 
Common Kestrel (Falco tinnunculus)

This species is also widely distributed in the inland region from $6^{\circ} 10^{\prime} 0^{\prime \prime} \mathrm{E}$ to the Algerian-Tunisian border (Fig. 9). Nests are typically found on high cliff, on rock ledges, and also on high-rise buildings. Guelma and Souk-Ahrass are the two provinces most occupied by breeding kestrels.

\section{Egyptian Vulture}

(Neophron percnopterus)

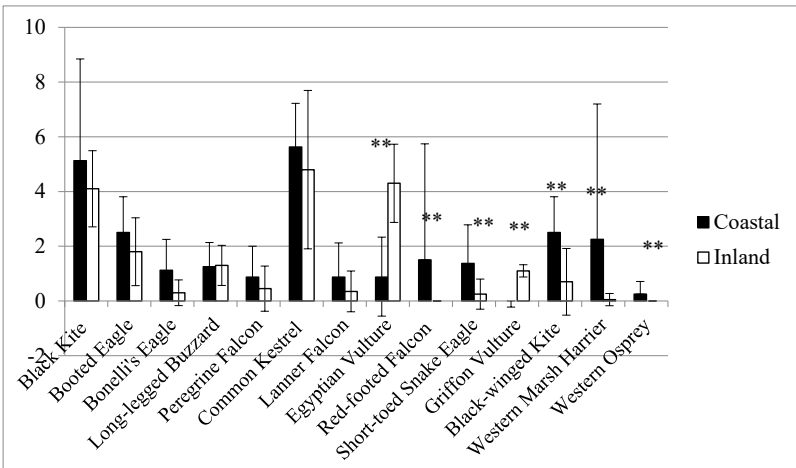

Fig. 5. Mean number of individuals $( \pm S D)$ detected per route during raptor surveys in the coastal and inlands regions of northeastern Algeria during the breeding seasons ( ${ }^{* *}$ significant differences).

Seven vultures nesting sites

have been recorded in northeastern Algeria, exclusively in the inland region (Fig. 10). The number of active nesting sites varied from 1 to 4 . Souk Ahras province seems to be the most important nesting area for this endangered raptor species.

\section{Booted Eagle (Hieraaetus pennatus)}

All the nesting sites reported in this study were located within Guelma province (Fig. 11). All active sites are shared by little number of pairs, less than 3 .

\section{Discussion}

Despite high raptor diversity and species of conservation importance, little is known about the structuring of raptor communities in North African regions. Almost all studies were focused on

$\mathrm{T}$ a b l e 3. Different nest types and their location (number of nests) detected during diurnal raptor surveys in the north-east of Algeria during the tow breeding seasons (2014 and 2015).

\begin{tabular}{|c|c|c|c|c|c|}
\hline \multirow{2}{*}{ Species } & \multicolumn{3}{|c|}{ Tree-nesting raptors } & \multirow{2}{*}{ Cliff-nesting raptors } & \multirow{2}{*}{ Settelment } \\
\hline & Cork oak & Eucalyptus & Pine & & \\
\hline Black Kite & 2 & & & 82 & \\
\hline Booted Eagle & 1 & & & 10 & \\
\hline Bonelli's Eagle & & & & 2 & \\
\hline Long-legged Buzzard & & 1 & & 4 & \\
\hline Peregrine Falcon & & & & 7 & \\
\hline Common Kestrel & & & & 57 & 12 \\
\hline Lanner Falcon & & & & 5 & \\
\hline Egyptian Vulture & & & & 19 & \\
\hline Black-winged Kite & & 2 & 1 & & \\
\hline Total & 3 & 3 & 1 & 186 & 12 \\
\hline
\end{tabular}




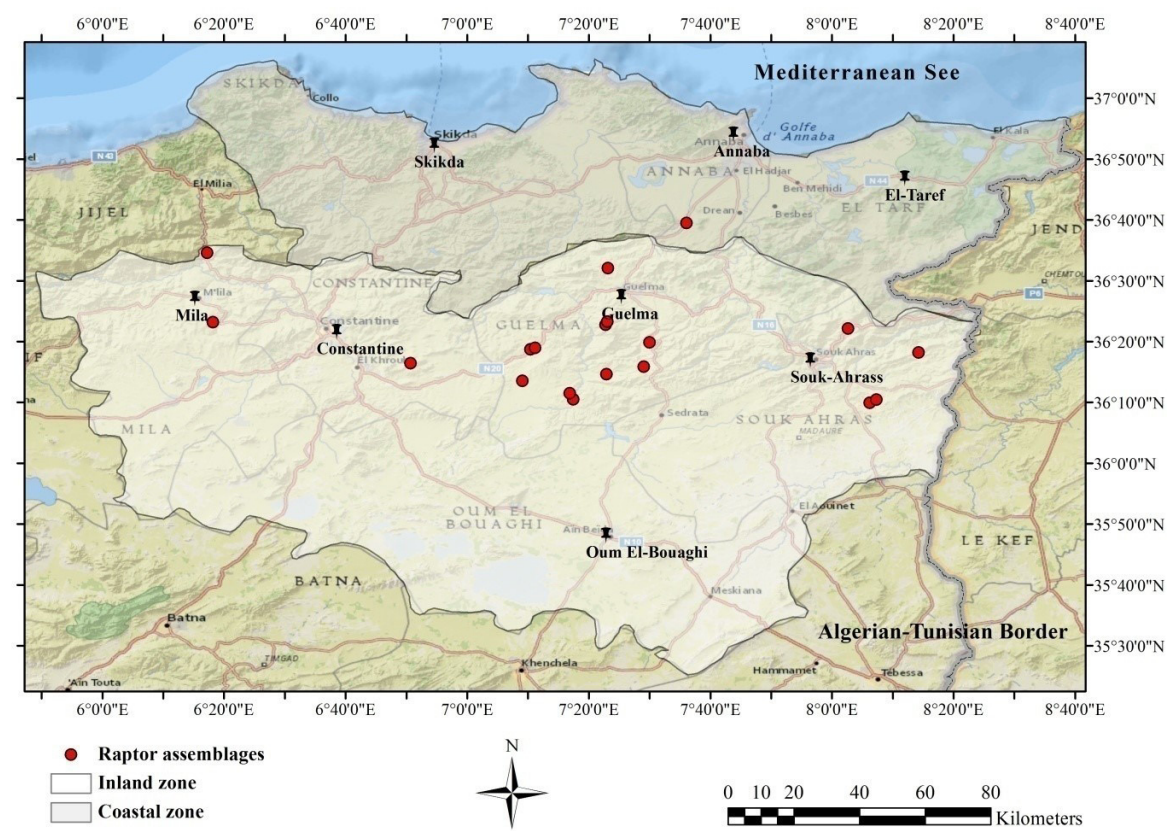

Fig. 6. Raptor breeding assemblages detected during raptor surveys in the north-east of Algeria during the two breeding seasons (2014 and 2015) (MapInfo, 2010).

tropical regions (including all countries between the Tropic of Cancer and Tropic of Capricorn; see Virani, Watson, 1998). Also, most of the available information about raptors in Algeria and the rest of North African countries is decades old. Indeed, the field study of Moali and Gaci (1992) in late 1980s remains one of the last studies about breeding raptors in the region. Since then, studies are few and far between; the accessible finding is especially about vultures status in Algeria and the other North African

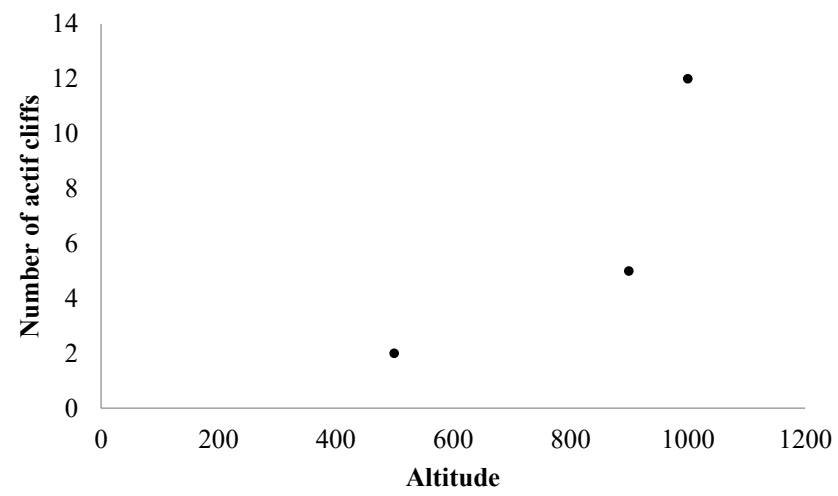

Fig. 7. Relationship between altitude and number of active cliffs. countries (such as in Amezian, El Khamlichi, 2015; Cherkaoui, 2005; Djardini et al., 2014) or about the dietary and nesting characteristics of some single species (as in Manaa et al., 2013; Telailia et al., 2013). Therefore, this article is the first to illustrate at a relatively broad-scale (about 31,000 $\mathrm{km}^{2} / 3,120,000 \mathrm{ha}$ ) the spatiotemporal (mapping) evolu- 


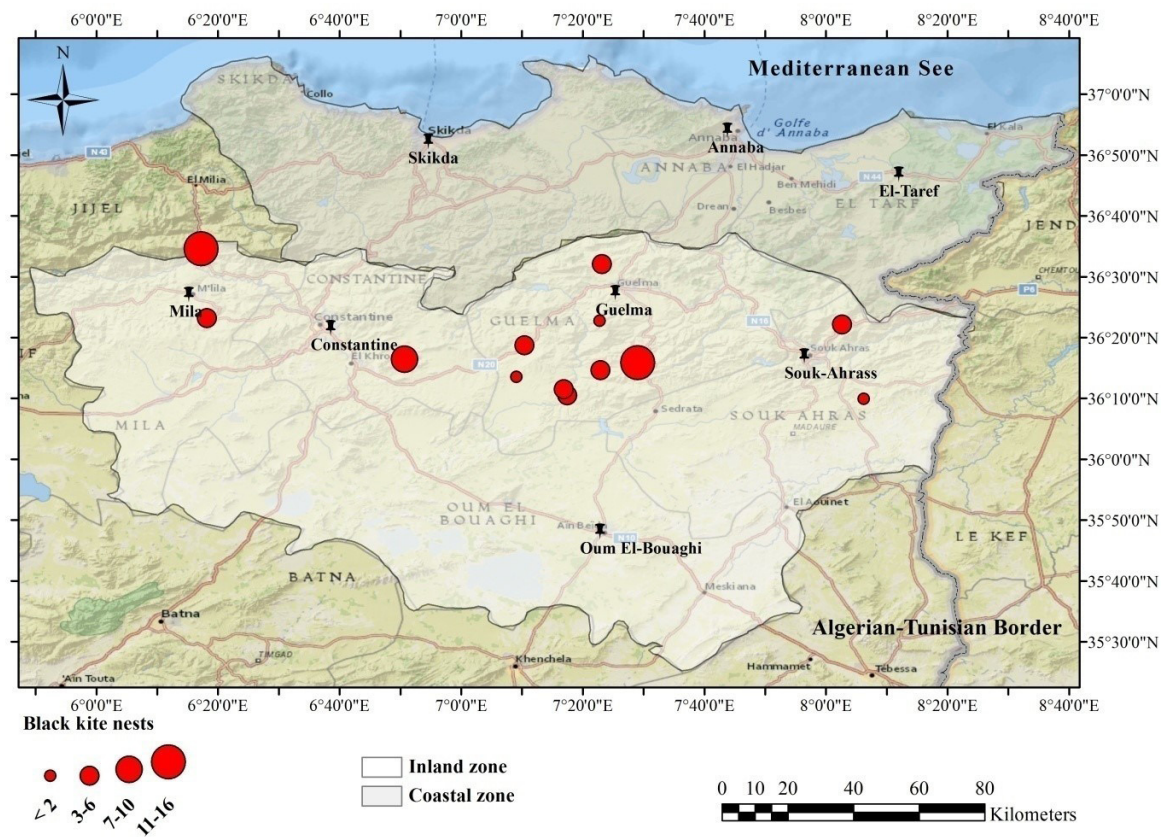

Fig. 8. Geospatially referenced map of the most important black kite nesting areas (MapInfo, 2010).

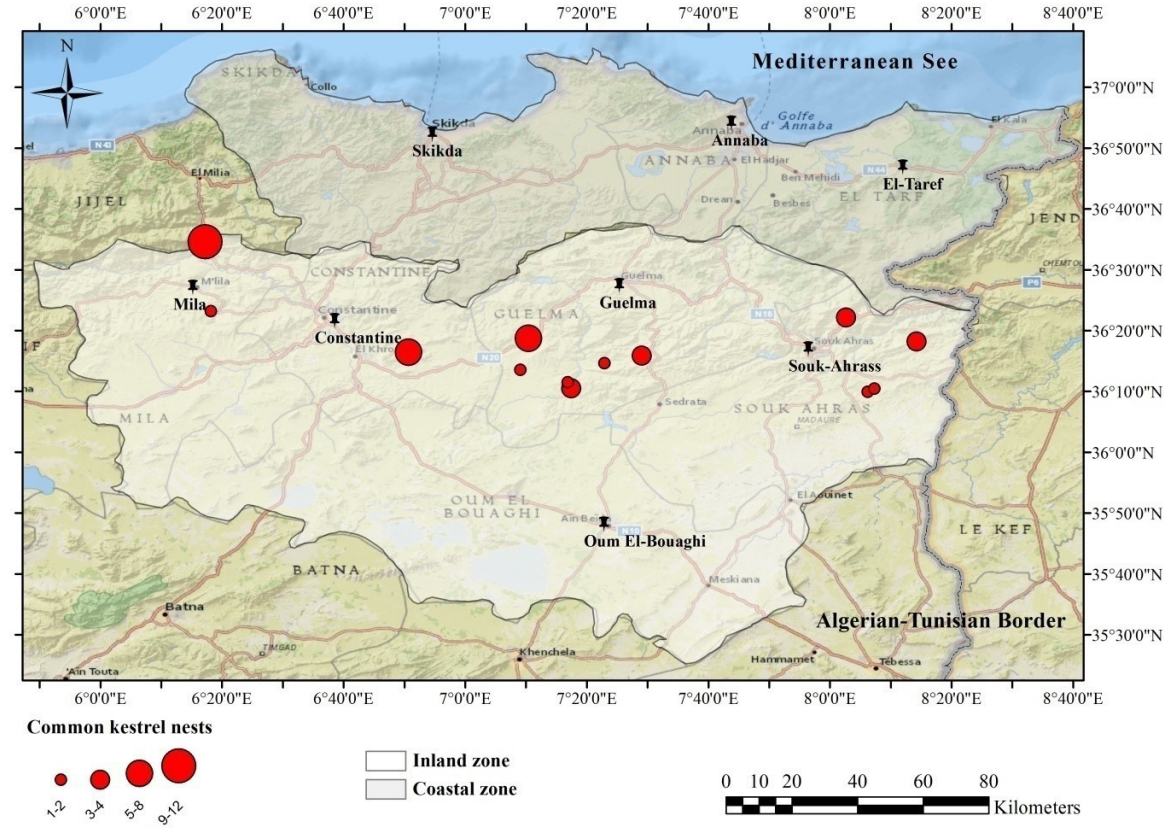

Fig. 9. Geospatially referenced map of the most important common kestrel nesting areas (MapInfo, 2010). 


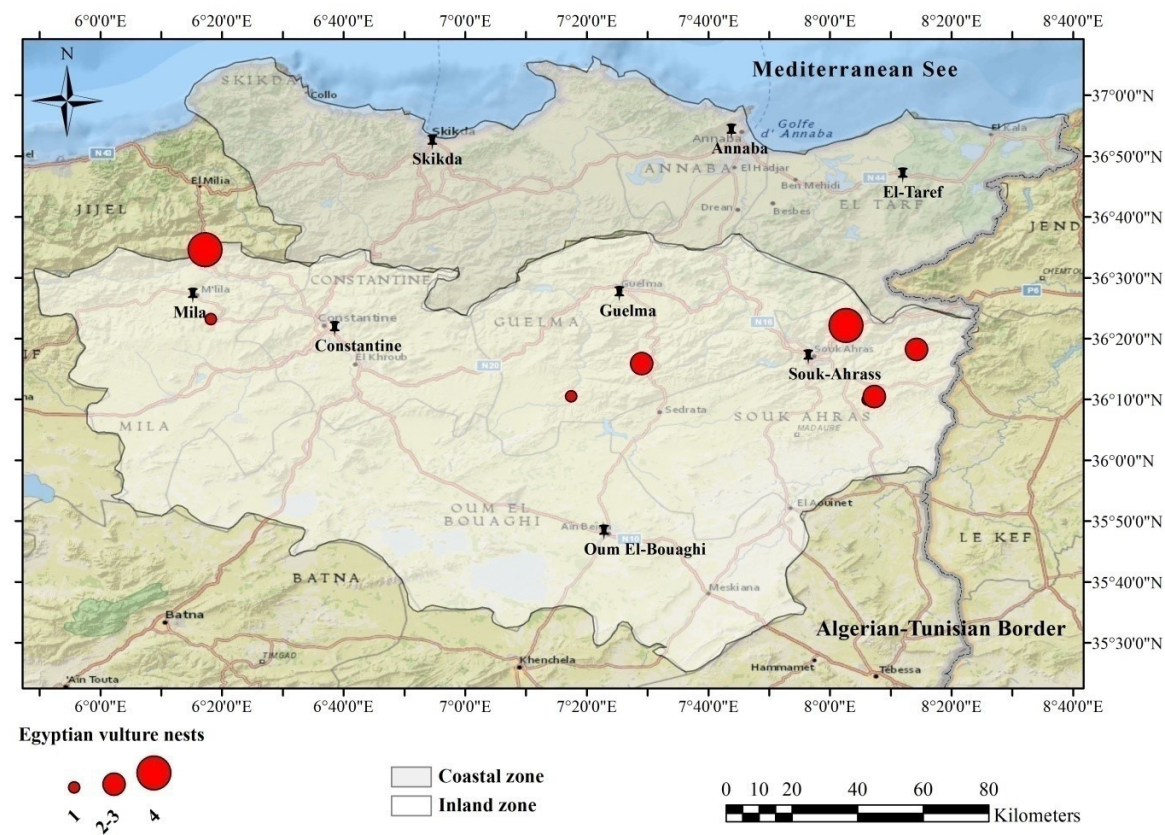

Fig. 10. Geospatially referenced map of the most important Egyptian vulture nesting areas (MapInfo, 2010).

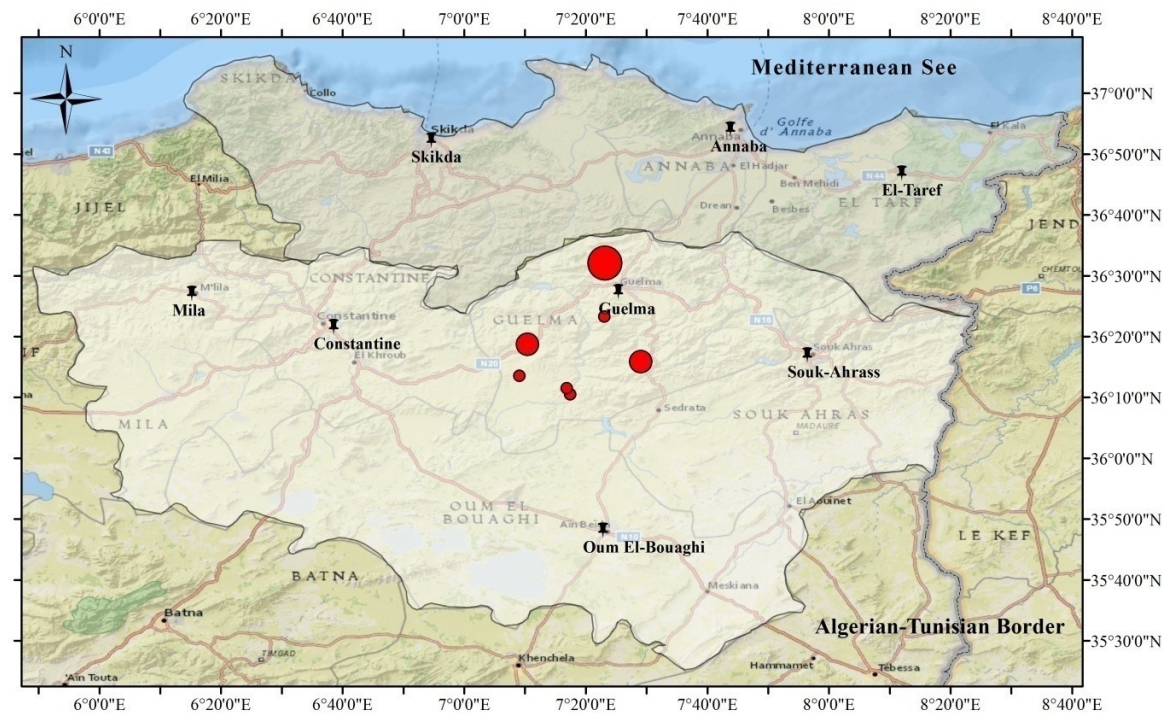

Booted eagle nests

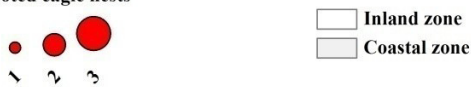

$\begin{array}{llllll}0 & 10 & 20 & 40 & 60 & 80\end{array}$

123

Kilometers

Fig. 11. Geospatially referenced map of the most important booted eagle nesting areas (MapInfo, 2010). 
tion of the breeding raptor populations observed consistently in two consecutive years of study. Although the study covered a limited area (raptor individual's required large geographic areas), the surveyed avifauna was found to be diverse. It was represented by almost half (14 species) of the nesting raptor species described in Algeria (30 species listed by Moali and Isenmann, 1990). Meanwhile, the area seems to be less diversified when compared with the Kabylie region of northern Algeria (18 species identified by Moali and Gaci, 1992). Differences in species richness may be consequence of considerable landscape variations between the two regions. The occurrence of the Kabylie region within the Tell Atlas mountains (high landscapes), which is almost designated as national protected park (Djurdjura) (Moali, Gaci,1992), probably contributes to the maintain of diversified raptor populations when compared with the study region (almost extended landscapes) that is often subjected to intense agricultural and agribusiness activities (two-thirds of the total study area; Isenmann, Moali, 2000; PASNB, 2003). It is well known that the significant changes in the conditions of existence of biota species occurred under intensive human impact on the environment (Blinkova, Shupova, 2017). Intensification of agriculture and high levels of pesticide use threaten many raptor species because they result in reduced prey availability in the region (Karakas, 2015; Thiollay, 2006). The relatively high value of the region is mainly attested by the occurrence of important numbers of threatened species such as Egyptian vulture and red-footed falcon. With 19 active nests found, we can confirm that Algeria has the largest population of the breeding Egyptian vulture in the Maghreb (Morocco, Algeria, Tunisia, and Libya; in the Middle Atlas Mountains of Morocco, Amezian and El Khamlichi (2015) counted a total of 48 nesting Egyptian vultures). Despite their breeding status (Isenmann, Moali, 2000), the red-footed falcon was only observed associated with rubbish dumps (36.689064 N. 7.699592 E) in El Taref Province (coastal region) and no active nests have been found.

Raptor species show a varying level of differentiation in nest-site characteristics (Poirazidis et al., 2007), but the large-scale spatial analyses of our region illustrated further similarities. We indicated that almost all raptor species ( $90 \%$ of all nests detected) preferred to nest within multispecies assemblages (mixed colonies). It has been observed that juvenile and adult survival is higher for individuals born or living in high-density areas, at least in some populations (Forero et al., 2002). All these loose colonies occupied altitudinal cliffs within the inland region (semi-arid zones) rather than coastal region. Cliff height is fundamental for a species of such size and weight (Cramp, Simmons, 1980). High-elevation cliffs generate strong updrafts and produce optimum flight conditions for soaring raptors (Pennycuick, 1973). Especially for vultures, this result is consistent with some regions of continental Europe where colonies are also restricted on cliffs located at higher altitude (Xirouchakis, Mylonas, 2005). Also, the nesting richness of the inland region is probably due to their semi-arid character (Isenmann, Moali 2000; PASNB, 2003), as suggested by some results found in southeastern Spain, where a number of raptor species usually favor semiarid landscapes with large steep cliffs (Martínez et al., 2008).

In urban environments, only the common kestrel seems to be relatively able to breed within cities and is the most synanthropic species, mainly attracted by the abundance of feeding (as rabbit availability) and nesting resources (high-rise buildings) (Donázar et al., 2016). In contrast, the remainder species are very sensitive and occupied only natural areas, very far from any human activities. 
The reason for this cliffs selection across the study area may be explained by a combination of factors acting synergically: (1) the heterogeneous distribution of resources, the region is characterized by high elevations and grasslands forming mosaics with oak, alpine, and cedar forests, which are patchily distributed; (2) non-natural mortality caused by man, for example, illegal hunting, electrocution, or collision with electricity cables or pylons.

Because of their large area requirements and trophic specialization, raptors have been proposed as indicator species of habitat quality (Blendinger et al., 2004). It is thought that an area of habitat sufficient to maintain a viable population of all members of a raptor assemblage should be large enough to maintain many other species as well. The main conclusion derived from our study is that altitudinal rocky cliffs surrounded by grasslands and forests are important for the conservation of raptors. Also we have provided a first spatial localization of the most important nesting areas of diurnal raptors and first evaluation of their population size and status [not yet included in the last updated African Raptor DataBank (ARDB, 2007)]. Knowledge obtained from this study is expected to be useful for raptor researchers to monitor and build a strong future study in order to preserve the remarkable diversity of these emblematic species in northeastern Algeria and implement a sound strategy for their effective safeguarding.

\section{References}

Amezian, M. \& El Khamlichi R. (2015). Significant population of Egyptian Vulture Neophron percnopterus found in Morocco. Ostrich: Journal of African Ornithology, 87, 73-76. DOI: 10.2989/00306525.2015.1089334.

ARDB (2007). The African Raptor DataBank (ARDB). http://www.habitatinfo.com/ardb_resources/ on 02/02/2017.

Bierregaard, R.O. Jr. (1998). Conservation status of bird of prey in the South American tropics. J. Raptor Res., 32, 19-27.

Bildstein, K.L., Schelsky, W., Zalles, J. \& Ellis S. (1998). Conservation status of tropical raptors. J. Raptor Res., 32, 3-18.

Bildstein, K.L. (2006). Migrating raptors of the world: their ecology \& conservation. Ithaca: Comstock Pub. Associates.

Bird, D.M. \& Bildstein K.L. (2007). Raptor research and management techniques. Surrey: Hancock House.

Blendinger, P.G., Capllonch, P. \& Alvarez M.E. (2004). Abundance and distribution of raptors in the Sierrade San Javier Biological Park, Northwestern Argentina. Ornitol. Neotrop., 15, 501-512.

Blinkova, O. \& Shupova T. (2017). Bird communities and vegetation composition in the urban forest ecosystem: correlations and comparisons of diversity indices. Ekológia (Bratislava), 36(4), 366-387. DOI: 10.1515/eko-2017-0029.

Brambilla, M., Rubolini, D. \& Guidali F. (2004). Rock climbing and raven Corvus corax occurrence depress breeding success of cliff-nesting peregrines Falco peregrines. Ardeola, 51(2), 425-430.

Cherkaoui, I. (2005). The Bearded Vulture Gypaetus barbatus in Morocco. Vulture News, 52, 37.

Coulthard, N.D. (2001). Algeria. In L.D.C. Fishpool \& M.I. Evans (Eds.), Important bird areas in Africa and associated islands: priority sites for conservation (pp. 51-70). BirdLife Conservation Series No. 11. Newsbury, Cambridge: Pisces Publications and BirdLife International.

Cramp, S. \& Simmon K.E.L. (Eds.) (1980). The birds of Western Palearctic. Vol. II. London: Oxford University Press.

Djardini, L., Ouar, D. \& Fellous A. (2014). Le Gypaète barbu dans le ciel du Parc National de Theniet El Had. Atlantica, $1,3-4$.

Donázar, J.A., Cortés-Avizanda, A., Fargallo, J.A., Margalida, A., Moleón, M., Morales-Reyes, Z., Moreno-Opo, R., PérezGarcía, J.M., Sánchez-Zapata, J.A., Zuberogoitia, I. \& Serrano D. (2016). Roles of raptors in a changing world: from flagships to providers of key ecosystem services. Ardeola, 63(1), 181-234. DOI: 10.13157/arla.63.1.2016.rp8.

Ferguson-Less, J. \& Christie D.A. (2001). Raptors of the world. Boston: Houghton Mifflin Company.

Forero, M.G., Donázar, J.A. \& Hiraldo F. (2002). Causes and fitness consequences of natal dispersal in a population the Black Kites. Ecology, 83(3), 858-872. DOI: 10.1890/0012-9658(2002)083[0858:CAFCON]2.0.CO;2.

Isenmann, P. \& Moali A. (2000). Oiseaux d’Algérie. Paris: S.E.O.F.

Jensen, W.J., Gregory, M.S. \& Baldassarre G.A. (2005). Raptor abundance and distribution in the Llanos wetlands of Venzuela. J. Raptor Res., 39(4), 417-428. 
Karakaș, R. (2015). Current status and distribution of diurnal raptor species in the south-eastern Anatolia Region, Turkey. Slovak Raptor Journal, 9(1), 105-113. DOI: 10.1515/srj-2015-0008.

Kirk, D.A. \& Hyslop C. (1998). Population status and recent trends in Canadian raptors: a review. Biol. Conserv., 83(1), 91-118. DOI: 10.1016/S0006-3207(97)00051-7

Magurran, A.E. (1988). Ecological diversity and its measurement. Princeton: Princeton University Press.

Manaa, A., Souttou, K., Sekour, M., Bendjoudi, D., Guezoul, O., Baziz-Neffah, F., Doumandji, S., Stoetzel, E. \& Denys C. (2013). Diet of Black-shouldered Kite Elanus caeruleus in a farmland area near Algiers, Algeria. Ostrich: Journal of African Ornithology, 84(2), 113-117. DOI: 10.2989/00306525.2013.781551.

Martínez, J.E., Martínez, J.A., Zuberogoitia, I., Zabala, J., Redpath, S.M. \& Calvo J.F. (2008). The effect of intra- and interspecific interactions on the large-scale distribution of cliff-nesting raptors. Ornis Fenn., 85, 13-21.

Moali, A. \& Isenmann P. (1990). The timing of breeding and clutch size of Blue Tits (Parus caeruleus) in two montane habitats in Algeria. In J. Blondel, A. Gosler, J.D. Lebreton \& R. McCleery (Eds.), Population biology of Passerine Birds (pp. 117-120). NATO ASI Series, 24. Berlin, Heidelberg: Springer. DOI: 10.1007/978-3-642-75110-3_9.

Moali, A. \& Gaci K. (1992). Les rapaces diurnes nicheurs en Kabylie (Algérie). Alauda, 60(3), 164-169.

PASNB (2003). Plan d'Action et Stratégie Nationale sur la Biodiversité. Rapport de Synthèse sur « La Conservation in situ et ex situ en Algérie » MATE-GEF/PNUD : Projet ALG/97/G31. Tome I à Tome IV.

Pennycuick, C.J. (1973). The soaring flight of vultures. Sci. Am., 229, 102-109.

Piana, R.P. \& Marsden S.J. (2012). Diversity community structure and niche characteristics within a diurnal raptor assemblage of northwestern Peru. The Condor, 114(2), 279-289. DOI: 10.1525/cond.2012.100163.

Poirazidis, K., Goutner, V., Tsachalidis, E. \& Kati V. (2007). Comparison of nest-site selection patterns of different sympatric raptor species as a tool for their conservation. Anim. Biodivers. Conserv., 30(2), 131-145.

Samraoui, B. \& Samraoui F. (2008). An ornithological survey of the wetlands of Algeria: Important Bird Areas. Ramsar sites and threatened species. Wildfowl, 58, 71-98.

Souttou, K., Baziz, B., Doumandji, S., Denys, C. \& Brahimi R. (2006). Analysis of pellets from a suburban common kestrel Falco tinnunculus nest in El harrach, Algiers, Algeria. Ostrich : Journal of African Ornithology, 77(3-4), 175-178.

Souttou, K., Baziz, B., Doumandji, S., Denys, C. \& Brahimi R. (2007). Prey selection in the common kestrel, Falco tinnunculus (Aves, Falconidae) in the Algiers suburbs (Algeria). Folia Zool., 56(4), 405-415.

Smith, D.G. \& Murphy J.R. (1973). Breeding ecology of raptors in the eastern great basin of UTAH. Biological Series, 18(3), 73.

Telailia, S., Saheb, M., Boutabia, L., Bensouilah, M.A. \& Houhamdi M. (2013). Breeding biology of Eleonora’s Falcon, Falco eleonorae Gené, 1839 (Accipitriformes Falconidae), in Northeast Algeria at Sérigina Island. Biodiversity Journal, 4(1), $117-124$.

Thiollay, J.M. (1977a). Importance des populations de rapaces migrateurs en Méditerranée occidentale. Alauda, 45, $115-121$.

Thiollay, J.M. (1977b). L'importance des hivernants paléarctiques dans le peuplement de rapaces d'Afrique tropicale. Nos Oiseaux, 34, 59-64.

Thiollay, J.M. (1989). Distribution and Ecology of Palearctic Birds of Prey Wintering in West and Central Africa. In B.U. Meyburg \& R.D. Chancellor (Eds.), Raptors in the modern world (pp. 95-107). Berlin, London, Paris: WWGBP.

Thiollay, J.M. (2006). The decline of raptors in West Africa: long-term assessment. human pressure and role of protected areas. Ibis, 148(2), 240-254.

Thiollay, J.M. (2007). Raptor communities in French Guiana: Distribution, habitat selection, and conservation. J. Raptor Res., 41, 90-105. DOI: 10.3356/0892-1016(2007)41[90:RCIFGD]2.0.CO;2.

ULRP (2013). Utah Legacy Raptor Project. Utah West Desert Raptors Nest Survey and Monitoring Protocol Manual. Department of Defense. Legacy Resources Management Program (Project \#10-102).

Virani, M. \& Watson R.T. (1998). Raptors in the east African tropics and western Indian Ocean islands: state of ecological Knowledge and conservation status. J. Raptor Res., 32(1), 28-39.

Watson, R.T. (1998). Preface - conservation and ecology of raptors in the tropics. J Raptor Res., 32, 1-2.

Weidensaul, S. (1996). Raptors: the birds of prey. New York: Lyons \& Burford.

Xirouchakis, S.M. \& Mylonas M. (2005). Selection of breeding cliffs by Griffon Vultures Gyps fulvus in Crete (Greece). Acta Ornithol., 40, 155-161. DOI: 10.3161/068.040.0211.

Zilio, F., Bolzan, A., De Mendonça-Lima, A., Da Silva, O., Verrastro, C.L. \& Borges-Martins M. (2013). Raptor assemblages in grasslands of Southern Brazil: species richness and abundance and the influence of the survey method. Zool. Stud., 52, 27. DOI: $10.1186 / 1810-522 \mathrm{X}-52-27$. 